\title{
PROMOTING EMOTIONAL INTELLIGENCE IN VOCATIONAL EDUCATION AS A METHOD TO ACHIEVE EMPLOYABILITY OF GRADUATES
}

\author{
ANita Līce ${ }^{1}$, Biruta SLOKA ${ }^{2}$ \\ University of Latvia (Latvia)
}

\begin{abstract}
Emotional intelligence can play an important role in an individual's education and career success. The purpose of this study is to evaluate the opinion of employers on the importance of competencies related to emotional intelligence in the recruitment process in Latvia, as well as the extent to which these competencies can be developed in vocational education and training. Total of 750 companies participated in this research, rating the importance of competencies and the performance of vocational education institutions using a four-point Likert scale. The list of methods currently applied in vocational education developing emotional intelligence competencies was developed through in-depth interviews with the managers of vocational education institutions. The research results show that most of employers evaluate ability to work independently, work motivation and problem-solving skills as very important in the recruitment process. Vocational education institutions need to pay more attention to improving ability to take responsibility in students. The main methods used by vocational education institutions to develop competencies linked to emotional intelligence are extra-curriculum activities, international events and mobility, as well as work-placements, which are supplements to education programmes rather than core curriculum, indicating to low link between emotional intelligence competencies and expected learning outcomes of vocational education. The research provides the basis for reconsidering the vocational education curriculum in the light of its contribution to development of competencies that are highly valued in the labour market. KEYWORDS: emotional intelligence, employability, vocational education.
\end{abstract}

JEL CODES: M51

DOI:

\section{Introduction}

The education system should consider the need to prepare graduates not just for immediate employment after graduation in their occupations but for sustainable employability in competitive and changing labour market. Līce and Sloka (Līce, Sloka, 2019: 8) found that vocational education in Latvia does not develop competencies and attitudes which are linked to person's self-management and emotional intelligence despite the fact that emotional intelligence has positive effect on personal performance. In competitive and changing labour market conditions, graduates are required to cooperate with other people, solve complex problems and constantly adapt to changing situations. Emotional intelligence can help individuals to operate in a socially complex world with multi-level, interdisciplinary challenges and to be self-aware of one's role, impact and needs.

1 Anita Līce - University of Latvia, Faculty of Pedagogy, Psychology and Arts; Faculty of Business, Management and Economics - researcher in the National Research Program INTERFRAME-LV; Employers' Confederation of Latvia (LDDK), scientific field - employability of graduates

E-mail: Anita.Lice@gmail.com

Tel. +371 29199276

2 Biruta Sloka - University of Latvia, Faculty of Business, Management and Economics - professor and senior researcher in the National Research Program INTERFRAME-LV

Scientific interests: management decision making, influence of education level on employability

E-mail: Biruta.Sloka@lu.lv

Tel.: +37129244966 
Problem. Although the goal of vocational education is to prepare graduates for the labor market, it does not develop competencies and attitudes which are linked to person's self-management and emotional intelligence (Lìce, Sloka, 2019: 9) that are important for employability.

Purpose. The purpose of this study is to evaluate the opinion of employers on the importance of competencies related to emotional intelligence in the recruitment process in Latvia, as well as the performance of vocational education institutions in developing these competencies in students.

Object. Competencies related to emotional intelligence.

Tasks:

1) to examine employers' evaluations by conducted survey of employers, evaluating their opinion on the importance of competencies related to emotional intelligence in the recruitment process in Latvia, as well as the performance of vocational education institutions in developing these competencies in students;

2) to collect information on the methods applied in vocational education institutions aimed at developing competencies related to emotional intelligence by conducted interviews with VET managers;

3) to analyze research results and draw conclusions about the importance of competencies related to emotional intelligence in the labour market in Latvia, as well as the performance of vocational education in developing them, including the methods applied.

Methods. The methods of research included the analysis of scientific publications, a survey of employers $(n=750)$ and the in-depth, semi-structured interviews with the managers (directors or deputy directors) of vocational education institutions in Latvia $(n=12)$.

\section{Theoretical findings}

Considering the changing labour market, ensuring employability of graduates in the long term has become an important topic for education policy makers, managers and researchers. There is a broad consensus that learning to learn is critically important competence for everyone (Council of the European Union, 2018) to be able to adapt to new skills requirements in the circumstances of technological development, fragmented careers and increased uncertainty. Some of employability researchers have also listed emotional intelligence as one of the important aspects in achieving employability, for example, Yorke and Knight (2002) and Pool and Sewell (2007), however, whereas emotional intelligence is closely linked to a set of emotional and selfmanagement competencies that are essential to employability, it deserves a much higher profile. The competencies linked to emotional intelligence are especially important in complex jobs because a deficiency of these abilities can hinder the use of technical expertise or intellect a person may have.

According to Mayer and Salovey (1997: 29), emotional intelligence is a cognitive ability that is associated to general intelligence and consists of four different dimensions including perception of emotion, emotional facilitation, understanding emotions, and management of emotions (Mayer, Salovey, 1997: 29). This concept is closely linked to Gardner's interpersonal intelligence, which he defined as the ability to understand other people, motivate them, how they work, how to work practically with them (Gardner, 1983: 29). More broadly, he defined intelligence as an ability to solve a problem (Gardner, 1983: 25). Goleman (1998: 317) who has made a significant contribution to the promotion of emotional intelligence defined emotional intelligence as "the capacity for recognizing our own feelings and those of others, for motivating ourselves, and for managing emotions well in ourselves and in our relationships". He also argues that the term "emotional intelligence" most accurately describes various prime qualities and portable skills that keep people employable in the labour market without job security (Goleman, 1998: 4). According to Goleman (1998: 28), an emotional competence is a learned capability that results in outstanding performance at work. It determines one's potential for learning the practical skills that are based on its five elements: self-awareness, motivation, self-regulation, empathy, and adeptness in relationships (Goleman, 1998: 28). More recently, Pekaar, Bakker, van der Linden and Born (2018) developed and validated the scale to measure emotional intelligence, distinguishing between four factors: self- and other-focused emotion appraisal and emotion regulation. 
Emotional intelligence and how it affects the individual and organizational development is becoming more and more researched aspect by academic researchers. Most of the research has focused on the positive effects of emotional intelligence and understanding the competencies and strategies that foster successful education and business functioning.

The positive effects of emotional intelligence on the labour market outcomes has been empirically proven. Rode, Arthaud-Day, Ramaswami and Howes (2017: 83) showed that emotional intelligence has a significant and positive effect on subsequent salary levels as it helps individuals acquire the social capital needed to be successful in their careers. Wen, Huang and Hou (2019: 127) tested the positive effect of emotional intelligence and emotional labour strategies on job satisfaction.

The implications of emotional intelligence on the organizational development and organisational challenges have also been extensively researched, including marketing effectiveness of corporate organizations (Nwokah, Ahiauzu, 2009: 879), customer satisfaction (Kernbach, Schutte, 2005: 441), solving intercultural communication problems (Dimitrijević, Starčević, Marjanović, 2019: 106), effectiveness of leader role (Afzalur, Psenicka, 2005: 339). Hess and Bacigalupo (2010: 227) have found that behaviors attributed to emotional intelligence may benefit leading the knowledge-based organization and help to balance the interests of the individual and organization. Clarke (2010: 29) has researched relationships between emotional intelligence and specific teamwork behaviors, but Gantt and Agazarian (2004: 149) has introduced an idea of emotional intelligence as a systems phenomenon that is relevant at all system levels, organizational, group, role and individual level, showing how individuals can contribute to the organisational emotional intelligence.

Researchers have also extensively studied the role of various competencies closely linked to emotional intelligence in ensuring individual employability, including good communication skills, ability to work in a team, leadership, motivation, aspiration (Copps, Plimmer, 2014: 38; Pool, Qualter, Sewell, 2014: 285), ability to adapt (Fugate, Kinicki, Ashforth, 2004: 36) as well as self-competencies, efficacy and reflection (Bridgstock, 2009: 41; Copps, Plimmer, 2014: 39; Law, Watts, 2003: 4; Pool, Sewell, 2007: 286; Yorke, Knight, 2004: 26).

Recently often asked question by academic researchers and educators world-wide is "Can emotional intelligence and the competencies linked to it be trained?" - on those aspects extensive meta-analytical investigation was performed (Mattingly, Kraiger, 2019: 153) showing a moderate positive effect and encouraging researchers and practitioners to further develop strategies and methodologies to facilitate development of emotional intelligence competencies.

\section{Empirical research methodology}

A sample for the employer survey was created by multistage cluster sampling method. The answers to the questionnaire were collected by the research centre SKDS Ltd. First, the companies which were in the database of "SKDS" were contacted, then the companies from the public databases of companies were selected according to the random sampling method. The data were collected in two phases: 1) from 27.03.2017 until 04.04.2017, when 499 internet questionnaires were collected, and 2) from 05.04.2017.-03.05.2017, when 251 telephone interviews were conducted by 19 interviewers. For telephone interviews, there were 587 cases of non-response: in $87.6 \%$ of these cases respondents didn't want to participate in the interview, $7 \%$ - didn't have time and 5.5\% stopped answering during the interview. Considering the size of the general population, the margin of error (MOE) at $95 \%$ confidence level is $+/-4.0 \%$.

To assess the importance of certain skills, competencies and attitudes in the recruitment process, the Likert-type question was included in the questionnaire. The scale was bi-directional with 4 possible answers. An option "difficult to answer" was included as well. The list of items to be assessed was elaborated, based on the Emotional Competence Framework, developed by Daniel Goleman (Goleman, 1998: 326) and the list of employability attributes which resulted from operationalization of the CareerEDGE employability model (Pool, Qualter, Sewell, 2014: 311; Pool, Sewell, 2007: 286). The list of items was adapted to the needs of the target audience of employers and the limitations of the survey questionnaire. Additional questions on the profile of companies were included: sector, region, number of employees, and whether the company has had trainees in their company during the last 5 years. 
For data analysis of the survey results descriptive statistics were used: indicators of central tendency or location (arithmetic mean, mode, median), indicators of variability (range, standard deviation, standard error of mean).

Semi-structured, in-depth, interviews with managers of vocational education institutions in Latvia were conducted by Anita Līce in February and March 2018. In total, 12 interviews were conducted with 15 directors or deputy directors from 12 public vocational education institutions (out of 34 public vocational education institutions in Latvia), each 40 to 90 minutes long. The vocational education institutions were selected to ensure appropriate representation of all Latvian regions, education fields, education levels and institutional subordination. The interviewees were invited to comment the methods vocational education institutions have used to facilitate development of 17 specific competencies linked to employability - as mentioned above suggested by scientific research results, among those 11 were linked to emotional intelligence (ability to create new ideas, ability to work in a team, attitude to work, communication skills, presentation skills, target orientation, ability to adapt, ability to work independently, planning and self-organising skills, problemsolving skills, work motivation, ability to take responsibility). The interviewees were able to choose which competencies to comment on. The data were analysed by the content analysis method. First, the categories of mentioned methods were identified, and then the data were coded and quantified accordingly.

\section{Empirical findings}

The frequencies of employer evaluations on importance of selected competencies linked to emotional intelligence (ability to adapt, ability to work independently, planning and self-organising skills, target orientation, work motivation and problem-solving skills) in the recruitment process in Latvia are included in the following table 1.

Table 1. Distribution of employers' evaluations on the importance of selected competencies in the recruitment process

\begin{tabular}{|c|c|c|c|c|c|c|c|c|c|c|c|c|}
\hline \multirow[t]{2}{*}{ Evaluations by employers } & \multicolumn{2}{|c|}{$\begin{array}{l}\text { Ability to } \\
\text { adapt }\end{array}$} & \multicolumn{2}{|c|}{$\begin{array}{c}\text { Ability } \\
\text { to work } \\
\text { independently }\end{array}$} & \multicolumn{2}{|c|}{$\begin{array}{l}\text { Planning } \\
\text { and self- } \\
\text { organising } \\
\text { skills }\end{array}$} & \multicolumn{2}{|c|}{$\begin{array}{c}\text { Target } \\
\text { orientation }\end{array}$} & \multicolumn{2}{|c|}{$\begin{array}{c}\text { Work } \\
\text { motivation }\end{array}$} & \multicolumn{2}{|c|}{$\begin{array}{c}\text { Problem- } \\
\text { solving skills }\end{array}$} \\
\hline & $n$ & $\%$ & $n$ & $\%$ & $n$ & $\%$ & $n$ & $\%$ & $n$ & $\%$ & $n$ & $\%$ \\
\hline Very important & 356 & 47.5 & 454 & 60.5 & 278 & 37.1 & 284 & 37.9 & 417 & 55.6 & 374 & 49.9 \\
\hline Rather important & 343 & 45.7 & 272 & 36.3 & 360 & 48.0 & 363 & 48.4 & 296 & 39.5 & 327 & 43.6 \\
\hline Rather not important & 31 & 4.1 & 9 & 1.2 & 74 & 9.9 & 72 & 9.6 & 17 & 2.3 & 29 & 3.9 \\
\hline Not important & 4 & 0.5 & 2 & 0.3 & 18 & 2.4 & 8 & 1.1 & 4 & 0.5 & 4 & 0.5 \\
\hline Hard to evaluate & 16 & 2.1 & 13 & 1.7 & 20 & 2.7 & 23 & 3.1 & 16 & 2.1 & 16 & 2.1 \\
\hline Total & 750 & 100 & 750 & 100 & 750 & 100 & 750 & 100 & 750 & 100 & 750 & 100 \\
\hline
\end{tabular}

Source: Author's calculations based on Anita Līce conducted survey of employers in 2017, n =750, evaluation scale 1-4, where 1 - very important; 2 - rather important; 3 - rather not important; 4 - not important.

Survey data analysis indicate that the overall importance of the selected competencies in the labour market is very high. Proportion of positive answers exceeds $93 \%$ for (in decreasing order) ability to work independently, work motivation, problem-solving skills and ability to adapt, and $85 \%$ - for target orientation and planning and self-organizing skills. Employers have evaluated as the most important ability to work independently which received the biggest share of evaluations "very important" $-60.5 \%$, then followed by work motivation (55.6\% of employers rated as "very important"). As data of table 1 indicate, most of employers gave evaluations for all analysed aspects and only small part of employers had difficulties to evaluate (for almost all analysed aspects there were less than $3 \%$ of employers answering "hard to evaluate"). The main 
statistical indicators of employers' evaluations on the importance of analysed competences in the recruitment process are included in table 2 (cases where employers did not provide the evaluation are excluded).

Table 2. Main statistical indicators of employers' evaluations of the importance of selected competencies in the recruitment process

\begin{tabular}{|l|c|c|c|c|c|c|}
\hline & $\begin{array}{c}\text { Ability to } \\
\text { adapt }\end{array}$ & $\begin{array}{c}\text { Ability } \\
\text { to work } \\
\text { indepen- } \\
\text { dently }\end{array}$ & $\begin{array}{c}\text { Planning } \\
\text { and self- } \\
\text { organising } \\
\text { skills }\end{array}$ & $\begin{array}{c}\text { Target } \\
\text { orientation }\end{array}$ & $\begin{array}{c}\text { Work } \\
\text { motivation }\end{array}$ & $\begin{array}{c}\text { Problem- } \\
\text { solving skills }\end{array}$ \\
\hline Valid & 734 & 737 & 730 & 727 & 734 & 734 \\
\hline Missing & 0 & 0 & 0 & 0 & 0 & 0 \\
\hline Mean & 1.57 & 1.40 & 1.77 & 1.73 & 1.47 & 1.54 \\
\hline Std. Error of Mean & 0.022 & 0.020 & 0.027 & 9.025 & 9.021 & 0.022 \\
\hline Median & 2 & 1 & 2 & 2 & 1 & 1 \\
\hline Mode & 1 & 1 & 2 & 2 & 1 & 1 \\
\hline Standard Deviation & 0.603 & 0.530 & 0.727 & 0.679 & 0.573 & 0.600 \\
\hline Variance & 0.363 & 0.281 & 0.529 & 0.462 & 0.328 & 0.361 \\
\hline Range & 3 & 3 & 3 & 3 & 3 & 3 \\
\hline Minimum & 1 & 1 & 1 & 1 & 1 & 1 \\
\hline Maximum & 4 & 4 & 4 & 4 & 4 & 4 \\
\hline
\end{tabular}

Source: Author's calculations based on a survey of employers conducted by Anita Līce in 2017, $\mathrm{n}=750$, evaluation scale 1-4, where 1 - very important; 2 - rather important; 3 - rather not important; 4 - not important

Although the employers have used full evaluation scale for their evaluations, the mode and the median for all analysed aspects was either 1 or 2 (it means that importance of those aspects was recognized by employers). Data analysis indicate that ability to work independently; work motivation and problem solving skills have mode and median 1 - it means that most of employers evaluate them as very important. Arithmetic means of employer's evaluations show that average evaluation was highest for ability to work independently where the evaluations were rather similar for employers - with relatively small indicators of variability. The biggest differences in evaluations by employers (indicated by indicators of variability) were for good planning and self-organising skills, target orientation and ability to adapt.

Distribution of employers' evaluations on performance of vocational education institutions in developing the selected competencies is included in table 3.

Table 3. Distribution of employer's evaluations on the performance of vocational education in developing selected competencies

\begin{tabular}{|l|c|c|c|c|c|c|c|c|c|c|}
\hline \multirow{2}{*}{$\begin{array}{c}\text { Evaluations by } \\
\text { employers }\end{array}$} & \multicolumn{2}{|c|}{$\begin{array}{c}\text { Ability to work } \\
\text { in a team }\end{array}$} & $\begin{array}{c}\text { Planning and } \\
\text { self-organising } \\
\text { skills }\end{array}$ & $\begin{array}{c}\text { Communication } \\
\text { skills }\end{array}$ & \multicolumn{2}{c|}{$\begin{array}{c}\text { Presentation } \\
\text { skills }\end{array}$} & \multicolumn{2}{c|}{$\begin{array}{c}\text { Ability to take } \\
\text { responsibility }\end{array}$} \\
\cline { 2 - 13 }$y$ & $n$ & $\%$ & $n$ & $\%$ & $n$ & $\%$ & $n$ & $\%$ & $n$ & $\%$ \\
\hline fully develops & 31 & 4.1 & 278 & 37.1 & 22 & 2.9 & 284 & 37.9 & 10 & 1.3 \\
\hline rather develops & 306 & 40.8 & 360 & 48.0 & 279 & 37.2 & 363 & 48.4 & 165 & 22.0 \\
\hline rather not develops & 167 & 22.3 & 74 & 9.9 & 198 & 26.4 & 72 & 9.6 & 261 & 34.8 \\
\hline not develops & 36 & 4.8 & 18 & 2.4 & 27 & 3.6 & 8 & 1.1 & 94 & 12.5 \\
\hline hard to evaluate & 210 & 28.0 & 20 & 2.7 & 224 & 29.9 & 23 & 3.1 & 220 & 29.3 \\
\hline Total & 750 & 100 & 750 & 100 & 750 & 100 & 750 & 100 & 750 & 100 \\
\hline
\end{tabular}

Source: Author's calculations based on a survey of employers conducted by Anita Līce in 2017, n =750, evaluation scale 1-4, where 1 - develops very well; 2 - develops rather well; 3 - does not develop very well; 4 - does not develop at all 
Survey results indicate that employers had some difficulties to evaluate communication skills $(29.9 \%$ of employers), ability to take responsibility (29.3\% of employers) and ability to work in a team (28\% of employers), most of employers did not have difficulties in evaluating the planning and self-organising skills (only $2.7 \%$ of employers had difficulties to evaluate this aspect) and presentation skills (only $3.1 \%$ of employers had difficulties to evaluate this aspect). The main statistical indicators of employers' evaluations on the performance of vocational education in developing selected competencies are included it table 4 (cases where employers did not provide the evaluation are excluded).

Table 4. Main statistical indicators of employers' evaluations on the performance of vocational education in developing selected competencies

\begin{tabular}{|l|c|c|c|c|c|}
\hline & $\begin{array}{c}\text { Ability to work } \\
\text { in a team }\end{array}$ & $\begin{array}{c}\text { Planning and } \\
\text { self-organising } \\
\text { skills }\end{array}$ & $\begin{array}{c}\text { Communication } \\
\text { skills }\end{array}$ & $\begin{array}{c}\text { Presentation } \\
\text { skills }\end{array}$ & $\begin{array}{c}\text { Ability to take } \\
\text { responsibility }\end{array}$ \\
\hline Valid & 540 & 730 & 526 & 538 & 530 \\
\hline Missing & 0 & 0 & 0 & 0 & 0 \\
\hline Mean & 2.39 & 1.77 & 2,44 & 2.25 & 2.83 \\
\hline Std. Error of Mean & 0.030 & 0.027 & 0.029 & 0.029 & 0.032 \\
\hline Median & 2 & 2 & 2 & 2 & 3 \\
\hline Mode & 2 & 2 & 2 & 2 & 3 \\
\hline Standard Deviation & 0.697 & 0.727 & 0.658 & 0.663 & 0.732 \\
\hline Variance & 0.486 & 0.529 & 0.433 & 0.440 & 0.536 \\
\hline Range & 3 & 3 & 3 & 3 & 3 \\
\hline Minimum & 1 & 1 & 1 & 1 & 1 \\
\hline Maximum & 4 & 4 & 4 & 4 & 4 \\
\hline
\end{tabular}

Source: Author's calculations based on a survey of employers conducted by Anita Līce in 2017, n = 750, evaluation scale 1-4, where 1 - develops very well; 2 - develops rather well; 3 - does not develop very well; 4 - does not develop at all

Survey results indicate that employers had rather similar evaluations although full evaluation scale was used for all analysed aspects. Modal evaluation by employers most often was 2 and median evaluation was 2 (half of respondents gave evaluations 2 or less and half of respondents gave evaluations 2 or more) except for ability to take responsibility where mode and median was 3 (the evaluation "does not develop very well" was given by $49.2 \%$ of employers and $17.7 \%$ of employers made evaluation "does not develop at all", only $1.9 \%$ of employers evaluated this aspect with "develops very well" and $31.1 \%$ of employers evaluated ability to take responsibility with "develops rather well". It means that vocational education institutions need to pay more attention and devote serious work to improve ability to take responsibility in vocational education students. Employers were more optimistic about development of planning and self-organising skills in vocational education in Latvia as the arithmetic mean of those evaluations was 1.77 , however, variability of those evaluations were rather different (characterized by relatively big standard deviation and other indicators of variability).

The main results of the interviews with the managers of vocational education institutions on the methods institutions are applying to facilitate development of selected competencies are included in table 5 . The interviews showed that vocational education institutions apply extra-curriculum activities, international events and mobility, as well as work-placements as the main methods to develop competencies that are linked to emotional intelligence. 
Table 5. Number of vocational education institutions commenting development of competencies and the methods applied to develop them

\begin{tabular}{|c|c|c|c|c|c|c|c|c|c|c|c|c|c|c|c|}
\hline \multirow[b]{2}{*}{ Competence } & \multirow[b]{2}{*}{$\begin{array}{c}\text { Freq. } \\
\text { of men- } \\
\text { tions, } \\
N_{\text {max }}=12\end{array}$} & \multicolumn{14}{|c|}{ Methods to facilitate competence development } \\
\hline & & Uू. & 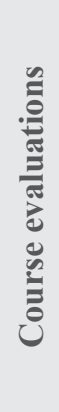 & 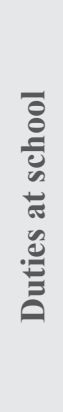 & 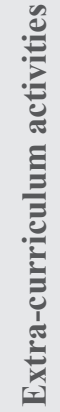 & 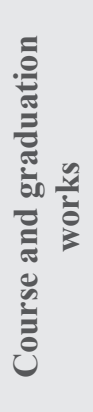 & 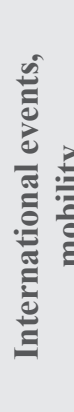 & 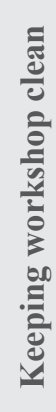 & 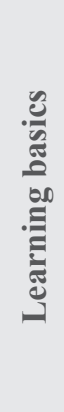 & 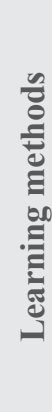 & 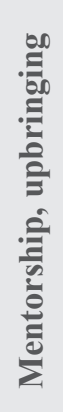 & 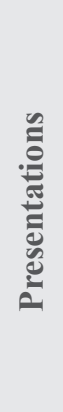 & 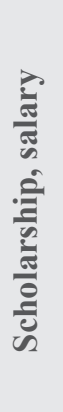 & 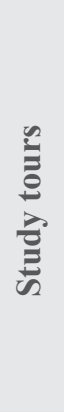 & 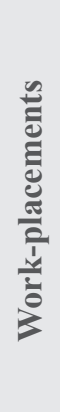 \\
\hline $\begin{array}{l}\text { Ability to create } \\
\text { new ideas }\end{array}$ & 5 & 1 & & & 3 & & 2 & & & & & & & & 2 \\
\hline $\begin{array}{l}\text { Ability to work in } \\
\text { a team }\end{array}$ & 6 & 1 & & & 3 & 1 & 2 & & & 4 & & & & 1 & 2 \\
\hline Attitude to work & 5 & & 1 & 1 & 2 & & 3 & 1 & & & & & 1 & & 3 \\
\hline $\begin{array}{l}\text { Communication } \\
\text { skills }\end{array}$ & 6 & & & & 5 & & 5 & & & 2 & 1 & 2 & & & 2 \\
\hline Presentation skills & 7 & & & & 2 & & 2 & & & & & 5 & & & 2 \\
\hline Target orientation & 4 & 1 & & & 3 & & 2 & & & & 1 & & & & 1 \\
\hline Ability to adapt & 7 & & & & 3 & & 3 & & 1 & & 1 & & & & 4 \\
\hline $\begin{array}{l}\text { Ability to work } \\
\text { independently }\end{array}$ & 6 & & & & 2 & & 2 & & & 3 & & & & & 2 \\
\hline $\begin{array}{l}\text { Planning and self- } \\
\text { organising skills }\end{array}$ & 6 & & 1 & & 4 & 1 & 2 & 1 & & & & & & & 2 \\
\hline $\begin{array}{l}\text { Problem-solving } \\
\text { skills }\end{array}$ & 5 & & & & 5 & & 2 & & & 1 & 1 & & & & 2 \\
\hline Work motivation & 3 & & & & 2 & & 2 & & & & & & 2 & & 2 \\
\hline $\begin{array}{l}\text { Ability to take } \\
\text { responsibility }\end{array}$ & 4 & & 1 & & 2 & & 2 & & & & & & & & 2 \\
\hline
\end{tabular}

Source: Anita Līce calculations based on interviews with managers of vocational education institutions conducted by Anita Līce in 2017, $\mathrm{n}=12$

Extra-curriculum activities are, by their nature, voluntary, and only most motivated or those having time engage. International mobility experience, however, is available to just $5.4 \%$ of vocational education students (Ministry of Education and Science, 2019). Although work-placements are obligatory part of vocational education programmes, they may be of various quality (Līce, 2018: 251) and may not provide useful knowledge and skills for work in occupation for as much as 20\% of students (Klāsons, Spuriņš̆, 2015: 41). Activities of core curriculum of vocational education such as learning methods, course evaluations, course and graduation works have been mentioned much more rarely by the managers as the methods to develop selected competencies. Most rarely commented competencies were work motivation, ability to take responsibility and target orientation indicating to difficulties for the managers of vocational education institutions to talk about these competencies as the learning outcome of vocational education. Considering that extra-curriculum activities, international events and mobility and work-placements do not constitute core curriculum of vocational education and that only part of students can benefit from engagement in them and obtaining useful learning experience, this indicates to limited opportunities for students to develop emotional intelligence competencies in vocational education in Latvia. 


\section{Conclusions}

Although development of competencies linked to emotional intelligence is very important in the recruitment process in Latvia, vocational education facilitate their development in students only on a moderate level. Most of employers evaluate ability to work independently; work motivation and problem-solving skills as very important in the recruitment process. Although employers evaluated positively the opportunities to develop planning and self-organising skills in vocational education in Latvia, however, their evaluations of vocational education performance indicate that institutions need to pay more attention and devote serious work to improve ability to take responsibility in students.

The main methods used by vocational education institutions to develop competencies linked to emotional intelligence are extra-curriculum activities, international events and mobility, as well as work-placements.

Considering that the activities which vocational education institutions apply most frequently to facilitate development of emotional intelligence competencies are supplements to vocational education programmes rather than core curriculum, their implementation to a large extent depends on external actors and factors (e.g., employers, affordability of students), and they reach only a portion of students, as well as the mediocre performance of VET institutions in facilitating development of student employability, the chances for all students to develop competencies linked to emotional intelligence are currently reduced.

\section{References}

Afzalur, R. M., Psenicka, C. (2005). Relationship between Emotional Intelligence and Effectiveness of Leader Role: A Dyadic Study in Four Countries. International Journal of Organizational Analysis, Vol. 13, No. 4, p. 3270342.

Bridgstock, R. (2009). The graduate attributes we've overlooked: enhancing graduate employability through career management skills. Higher Education Research \& Development, Vol. 28, No. 1, p. 31-44.

Hess, J., Bacigalupo, A. (2010). The emotionally intelligent leader, the dynamics of knowledge $\square$ based organizations and the role of emotional intelligence in organizational development. On the Horizon, Vol. 18, No. 3, p. 222-229.

Carmeli, A., Yitzhak-Halevy, M., Weisberg, J. (2009). The relationship between emotional intelligence and psychological wellbeing, Journal of Managerial Psychology, Vol. 24, No. 1, p. 66-78.

Clarke, N. (2010). Emotional intelligence abilities and their relationships with team processes. Team Performance Management, Vol. 16, No. 1/2, p. 6-32.

Copps, J., Plimmer, D. (2013). Inspiring Impact. The Journey to EmploymenT (JET) Framework. Outcomes and tools to measure what happens on young people's journey to employment, p. 1-76. Retrieved 01/08/2019 from https://www. thinknpc.org/wp-content/uploads/2018/07/JET-framework-FINAL-Jan-2015.pdf

Council of the European Union. (2018). Council Recommendation on Key Competences for Lifelong Learning. 9009/18. Brussels. Retrieved 01/08/2019 from http://data.consilium.europa.eu/doc/document/ST-9009-2018-INIT/EN/pdf

Dimitrijević, A. A., Starčević, J., Marjanović, Z. J. (2019). Can ability emotional intelligence help explain intercultural effectiveness? Incremental validity and mediation effects of emotional vocabulary in predicting intercultural judgment. International Journal of Intercultural Relations, Vol. 69, p. 102-109.

Fugate, M., Kinicki, A. J., Ashforth, B. E. (2004). Employability: A psycho-social construct, its dimensions, and applications. Journal of Vocational Behavior, Vol. 65, No. 1, p. 14-38.

Gantt, S., Agazarian, Y. (2004). Systems $\square$ Centered Emotional Intelligence: beyond Individual Systems to Organizational Systems, Organizational Analysis, Vol. 12, No. 2, p. 147-169.

Gardner, H. (1987). The theory of multiple intelligences. Annals of Dyslexia, Vol. 37(1), p. 19-35.

Goleman, D. (1998). Working with Emotional Intelligence. London: Bloomsbury.

Kernbach, S., Schutte, N. (2005). The impact of service provider emotional intelligence on customer satisfaction, Journal of Services Marketing, Vol. 19, No. 7, p. 438-444.

Klāsons, G., Spurinnš, U. (2015). Pētījums par prakšu pieejamību un kvalitāti Latvijā. Noslēguma ziņojums. [Study on availability and quality of work placements in Latvia. Final report]. Riga: Employers' Confederation of Latvia (LDDK). Retrieved 01/08/2019 from http://www.lddk.lv/wp-content/uploads/2015/06/LDDK_VET4E_Petijums _ prakses.pdf

Law, B., Watts, A. G. (2003). The DOTS analysis, original version. Cambridge: The Career Learning Network. Retrieved 15/07/2019 from http://www.hihohiho.com/memory/cafdots.pdf

Līce, A. (2018). Learning by Working: Examining Examples of Good Practice in Organising Work placements in Vocational Education. Learning Strategies and Constructionism in Modern Education Settings by IGI Global publishing 
house. ISBN13: 9781522554301, p. 250-267.

Lìce, A., Sloka, B. (2019). Performance of vocational education in Latvia in developing employability of graduates. SOCIETY. INTEGRATION. EDUCATION. Proceedings of the International Scientific Conference, Vol. 5. Rezekne, Rezekne Academy of Technologies, 2019, p. 222-232.

Mattingly, V., Kraiger, K. (2019). Can emotional intelligence be trained? A meta-analytical investigation. Human Resource Management Review, Vol. 29, No. 2, p. 140-155.

Mayer, J. D., Salovey, P. (1997). What is emotional intelligence? In P. Salovey, D. Sluyter (eds.). Emotional Development and Emotional Intelligence: Implications for Educators. New York, p. 3-31.

Ministry of Education and Science. (2019). Informatīvais ziņojums "Par Izglītības attīstības pamatnostādņu 2014.2020.gadam īstenošanas 2014.-2017.gadā starpposma novērtējumu”. [Informative Report “On Interim Evaluation of Implementation of Education Development Guidelines for 2014-2020”]. Ministry of Education and Science of Latvia.

Nwokah, G. N., Ahiauzu, A. (2009). Emotional intelligence and marketing effectiveness. Marketing Intelligence \& Planning, Vol. 27, No. 7, p. 864-881.

Pekaar, K. A., Bakker, A. B., van der Linden, D., Born, M. P. (2018). Self- and other-focused emotional intelligence: Development and validation of the Rotterdam Emotional Intelligence Scale (REIS). Personality and Individual Differences, Vol. 120, p. 222-233.

Pool, L. D., Qualter, P., Sewell, P. J. (2014). Exploring the factor structure of the CareerEDGE employability development profile. Education + Training, Vo. 56, No.4, p. 303-313.

Pool, L. D., Sewell, P. (2007). The key to employability: developing a practical model of graduate employability. Education + Training, Vol. 49, No. 4, p. 277-289.

Rode, J. C., Arthaud-Day, M., Ramaswami, A., Howes, S. (2017). A time-lagged study of emotional intelligence and salary. Journal of Vocational Behavior, Vol. 101, p. 77-89.

Wen, J., Huang, S., Hou, P. (2019). Emotional intelligence, emotional labor, perceived organizational support, and job satisfaction: A moderated mediation model. International Journal of Hospitality Management, Vol. 81, p. $120-130$.

Yorke, M., Knight, P. (2004). Embedding employability into the curriculum. Learning and Employability, Vol. 3, p. $1-28$.

The paper was supported by the project "INTERFRAME-LV"

\title{
EMOCINIO INTELEKTO SKATINIMAS PROFESINIO MOKYMO İTAIGOSE, SIEKIANT PADE்TI İIDARBINTI
}

\author{
Anita Līce, Biruta Sloka \\ Latvijos universitetas (Latvija)
}

\section{Santrauka}

Emocinis intelektas gali vaidinti svarbų vaidmenį, siekiant užtikrinti asmens išsilavinimą ir sėkmingą karjerą. Šiuo tyrimu siekta ịvertinti darbdavių nuomonę apie su emociniu intelektu susijusių kompetencijų svarbą įdarbinimo procese Latvijoje, pasidomèti, kaip šias kompetencijas galima būtų tobulinti profesiniame mokyme. Tyrime dalyvavo 750 įmonių, kurios įvertino kompetencijų svarbą ir profesinio mokymo ịstaigų veiklą pagal keturių balų Likerto skalę. Profesiniame mokyme taikomų metodų, ugdančių emocinio intelekto kompetencijas, sąrašas aptartas su profesinio mokymo įstaigų vadovais.

Tyrimo rezultatai atskleidè, kad dauguma darbdavių gebejjimą savarankiškai dirbti, darbo motyvaciją ir problemų sprendimo ịgūdžius vertina kaip ypač svarbius įdarbinimo procese. Profesinio mokymo įstaigos daugiau dèmesio turètų skirti studentų gebejjimui prisiimti atsakomybę ugdyti. Pagrindiniai metodai, kuriuos profesinio mokymo ịstaigos taiko ugdydamos su emociniu intelektu susijusias kompetencijas, yra popamo- 
kinè veikla, tarptautiniai renginiai, be to, skatinamas mobilumas - išvykos ị kitas šalis ar lankymasis kitose organizacijose. Taip igyvendinami numatomi profesinio mokymosi rezultatai ir ugdomas emocinis intelektas.

Tyrimas leidžia persvarstyti profesinio mokymo programą, siekiant ugdyti kompetencijas, kurios vertinamos darbo rinkoje. Kadangi veikla, kurią profesinio mokymo įstaigos dažniausia taiko ugdydamos emocinio intelekto kompetencijas, yra profesinio mokymo programų priedai, o ne pagrindinès programos, jų ígyvendinimas daug priklauso nuo išorinių veiksnių (pvz., darbdavių, studentų galimybių mokèti už mokymus), todèl tai pasiekia tik dalị studentų. Todèl svarbu, kad įsidarbinimo galimybės absolventams nemažètų ir jie galètų tobulinti su emociniu intelektu siejamas kompetencijas.

PAGRINDINIAI ŽODŽIAI: emocinis intelektas, ìsidarbinimo galimybès, profesinis išsilavinimas.

JEL KLASIFIKACIJA: M51

Received: 2019-08-20

Revised: 2019-09-10

Accepted:2019-09-20 